\title{
The effect of exercise training on leptin levels in obese males.
}

Citation for published version (APA):

Pasman, W. J., Westerterp, K. R., Plantenga, M. S., \& Saris, W. H. M. (1998). The effect of exercise training on leptin levels in obese males. American Journal of Physiology (Consolidated), 274(2 Pt 1), E280-E286. https://doi.org/10.1152/AJPENDO.1998.274.2.E280

Document status and date:

Published: 01/01/1998

DOI:

10.1152/AJPENDO.1998.274.2.E280

Document Version:

Publisher's PDF, also known as Version of record

\section{Please check the document version of this publication:}

- A submitted manuscript is the version of the article upon submission and before peer-review. There can be important differences between the submitted version and the official published version of record.

People interested in the research are advised to contact the author for the final version of the publication, or visit the DOI to the publisher's website.

- The final author version and the galley proof are versions of the publication after peer review.

- The final published version features the final layout of the paper including the volume, issue and page numbers.

Link to publication

\footnotetext{
General rights rights.

- You may freely distribute the URL identifying the publication in the public portal. please follow below link for the End User Agreement:

www.umlib.nl/taverne-license

Take down policy

If you believe that this document breaches copyright please contact us at:

repository@maastrichtuniversity.nl

providing details and we will investigate your claim.
}

Copyright and moral rights for the publications made accessible in the public portal are retained by the authors and/or other copyright owners and it is a condition of accessing publications that users recognise and abide by the legal requirements associated with these

- Users may download and print one copy of any publication from the public portal for the purpose of private study or research.

- You may not further distribute the material or use it for any profit-making activity or commercial gain

If the publication is distributed under the terms of Article $25 \mathrm{fa}$ of the Dutch Copyright Act, indicated by the "Taverne" license above, 


\title{
The effect of exercise training on leptin levels in obese males
}

\author{
W. J . PASMAN, ${ }^{1}$ M. S. WESTERTERP-PLANTENGA, ${ }^{2}$ AND W. H. M. SARIS ${ }^{1}$ \\ ${ }^{1}$ Maastricht University, Department of Human Biology, 6200 MD Maastricht; \\ and 2Open University, 6401 DL Heerlen, The Netherlands
}

\begin{abstract}
Pasman, W. J ., M. S. Westerterp-Plantenga, and W. H. M. Saris. The effect of exercise training on leptin levels in obese males. Am. J . Physiol. 274 (Endocrinol. Metab. 37): E280-E286, 1998.-The effect of endurance training on plasma leptin levels was investigated in 15 obese male subjects (age $37.3 \pm 5.2 \mathrm{yr}$, body weight $96.5 \pm 13.6 \mathrm{~kg}$, and body mass index $29.8 \pm 3.0 \mathrm{~kg} / \mathrm{m}^{2}$ ) in a weight loss and exercise program. After 4 mo of treatment consisting of a very low energy diet (VLED) and endurance exercise training (3-4 times weekly, $1 \mathrm{~h}$ sessions, moderate intensity), two groups were formed. One group continued the exercise sessions (trained subjects, $n=7$ ) and the other group stopped with the exercise program (control, $n=8$ ). Measurements of anthropometry, aerobic power, and fasted blood samples were executed at fixed time points $(0,2,4,10$, and $16 \mathrm{mo})$. With partial regression analysis, keeping the changes in insulin and body fat percentage constant, it was shown that the number of hours of exercise training was significantly correlated with changes in leptin levels, during the 16-mo period $(r=0.56, P<0.05)$. Changes in insulin levels were significantly related to the changes in leptin levels $(r=0.47, P<$ $0.05)$, which were less for changes in body fat percentage $(r=$ $0.42, P=0.07)$. During the VLED, the change in insulin concentration affected leptin levels significantly $(r=0.79)$ but changes in body fat percentage were not noted. It is concluded that endurance exercise training decreased plasma leptin levels independently of changes in plasma insulin levels and body fat percentage.
\end{abstract}

endurance training; insulin; obesity

THE ISOLATION OF the ob gene in mice by F riedman et al. (10) has renewed interest in body weight regulation and the pathophysiology of human obesity. The ob gene product leptin is secreted from adipocytes, and it is postulated that leptin acts as a humoral long-term feedback signal to the central nervous system and in particular to the satiety center in the hypothalamus (3, $27,32) . \mathrm{Ob} /$ ob mice not producing leptin responded to high levels of injected leptin with decreased food intake, a decrease in body weight, an increase in energy metabolism, and normalization of glucose and insulin concentrations (11, 24). In human studies it was found that obese subjects have high leptin concentrations, which might indicate that they are resistant to leptin. Several potential defects have been suggested such as 1) a defect in the blood-brain barrier transport, 2) a defect in the leptin receptor in the brain, or 3) a defect in the coupling with neuropeptideY resulting in altered food intake (27).

The relationship between fat mass and leptin, which is also found in humans (7), might be affected by mechanisms acting on fat mass. Theinsulin hormone is thought to be important in this control mechanism (8,
22). F eeding and starvation (an increase and a decrease of fat mass, respectively) have been found to affect leptin and insulin levels $(7,19)$. It has been suggested that insul in can be viewed as an up- and downregulator of ob gene expression as was shown in lean rats (8), whereas only upregulation was present and functional in obese animals. Circumstantial evidence suggests a role for the adipocyte in the genesis of insulin resistance. Recent work of Cohen and colleagues (5) suggested that secretion of leptin by an enlarged store of adipose tissue may cause insulin resistance, because of insulin-antagonizing effects of leptin $(5,33)$.

Not much information is available about the effect of long-term exercise on the relationship of body fat and leptin. I nasmuch as it is known that exercise can be of therapeutic value for diabetic patients, because of an increase in insulin sensitivity (4), the question arises concerning what the effect of exercise might be on the leptin-insulin interaction. Is an exercise intervention effective in relation to obesity by means of an adaptation of leptin levels related to changes in body fat?

In this study the effect of an exercise intervention after a weight loss treatment is studied in relation to long-term weight maintenance in obese male subjects. Changes in body weight, body fat percentage, insulin, and leptin concentrations were examined in relation to training status of the subjects. It is hypothesized that long-term endurance training might reduce leptin levels in relation to body fat, possibly mediated by insulin.

\section{METHODS}

Subjects. In this study, 15 sedentary obese males participated [age $37.3 \pm 5.2 \mathrm{yr}$, body mass index (BMI) $29.8 \pm 3.0$ $\mathrm{kg} / \mathrm{m}^{2}$, and body wt $\left.96.5 \pm 13.6 \mathrm{~kg}\right]$. Physical characteristics of the subjects before the study are given in Table 1 . Subjects were medically examined by a physician before they entered the study. The experimental procedures and potential risks of the study were explained both verbally and in writing. A written informed consent was obtained from each subject at the start of the study. The study was approved by the Ethics Committee of the Maastricht University.

Study design and protocol. All subjects started a very low energy diet (VLED), a protein-enriched formula diet providing 2 MJ daily ( $44 \%$ energy protein, $14 \%$ energy fat, $42 \%$ energy carbohydrate), for $2 \mathrm{mo}$ in addition to a training program of $4 \mathrm{mo}$. The exercise performed consisted of low- to moderate-intensity exercise bouts of $1 \mathrm{~h}$, three to four times a week. After the VLED, the training sessions were continued for another 2 mo to prevent a fast regain of the weight lost. After these 4 mo two groups were formed; one group continued the training sessions $(n=7)$ and the other group stopped training $(\mathrm{n}=8)$. The latter group served as the controls and performed sports activities less than once a week as before the intervention. Physical characteristics (the same as pre- 
sented in Table 1) were not significantly different between the trained and the control groups at $4 \mathrm{mo}$.

The group that continued training trained with a local triathlon club, where they could train under supervision at a moderate to severe intensity all three events of the triathlon (swimming, cycling, and running). They could also train by themselves, thereby not restricting them to certain training hours (because of shift-work some subjects were otherwise not able to train).

Compliance. Compliance to training sessions was checked in multiple ways. A training diary was used for day-to-day activities and remarks (illness, injury, weather conditions, and so forth). Questionnaires at the time of measurement to check frequency of training (number of training hours per week) and visitations of the investigator to training sessions were also performed to investigate compliance. Compliance to the prescribed training sessions was $89 \pm 26 \%$ for the trained group during the intervention period.

Measurements. After an overnight fast subjects came to the laboratory at $0,2,4,10$, and 16 mo after starting the study at $8 \mathrm{AM}$ for different measurements.

Anthropometry. Subjects were weighed on a digital balance accurate to $0.1 \mathrm{~kg}$ (Sauter D-7470, Ebingen, Germany). Height was obtained to the nearest $0.1 \mathrm{~cm}$ using a wallmounted stadiometer (Seca, model 220, Hamburg, Germany). The BMI was calculated by body weight $\times$ height $^{-2}\left(\mathrm{~kg} / \mathrm{m}^{2}\right)$. The distribution of fat was investigated by measuring the waist and hip circumferences and calculating the waist-to-hip ratio $(W H R)$ and sagittal diameter $\left(D_{\text {sag }}\right)$. The waist circumference was measured at the smallest circumference between the rib cage and the iliac crest, with the subject in the standing position. The hip circumference was performed at the level of the widest circumference between the waist and the thighs. The WHR was calculated by dividing the waist circumference by the hip circumference. F or determination of the $D_{\text {sag }}$, the distance between the abdomen and the back, a stadiometer was used with the subject in the supine position.

The deuterium dilution technique was used for measurement of body composition in this study (29). ${ }^{2} \mathrm{H}_{2} \mathrm{O}$ dilution was used to measure total body water (TBW). Subjects were asked to collect a urine sample in the evening just before drinking the deuterium-enriched water solution. After consumption of this solution no further consumption was allowed. Ten hours after drinking the water solution another urine sample was collected. The dilution of the deuterium isotope is a measure for TBW of the subject (20). Deuterium was measured in the urine samples with an isotope ratio mass spectrometer (VGI sogas Aqua Sira). TBW was obtained by dividing the measured deuterium dilution space by 1.04 (29). Fat-free mass was calculated by dividing the TBW by the hydration factor 0.73 .

Blood analysis. On all test days fasted blood samples were obtained (10 ml EDTA-blood and $10 \mathrm{ml}$ serum) from the subjects before 9 AM. Subjects were instructed not to perform strenuous exercise the day before the test day and train at least $12 \mathrm{~h}$ before blood sampling. The time period between the last exercise bout and blood sampling was always at least $12 \mathrm{~h}$. The plasma blood samples were mixed with EDTA to prevent clotting and were centrifuged immediately. Serum blood was centrifuged after $1 \mathrm{~h}$ at room temperature. Blood samples were stored at $-80^{\circ} \mathrm{C}$ until further analysis. Plasma insulin was measured using a double antibody radioimmunoassay (RIA) for human insulin (Kabi Pharmacia Diagnostics, Uppsala, Sweden). Leptin analysis was performed with an RIA (Linco Research, St. Charles, MO), based on a study of Maffei and colleagues (19). The within-assay analytic coefficient of variation of the RI A kit ranged from 3.4 to $8.5 \%$, and the interassay coefficient of variation ranged from 3.6 to $6.2 \%$. The within-subject of variation for repeated sampling was $2.9 \pm 2.4 \%$, whereas the between-subject coefficient of variation was $65.6 \%$. The values measured were in the range of detection (range $0.5-100 \mathrm{ng} / \mathrm{ml}$ ). All determinations of leptin levels were run in a single assay to eliminate interassay variation. Insulin and leptin were both determined in duplicate.

Maximal performance test. To investigate the effect of the training program on performance capacity [maximal oxygen uptake $\left(\mathrm{VO}_{2 \max }\right)$ and maximal power output $\left.\left(\mathrm{W}_{\max }\right)\right]$, an incremental exercisetest was performed on an el ectromagnetically braked cycle ergometer (Lode, Groningen, The Netherlands). After a warm-up period of $9 \mathrm{~min}(5 \mathrm{~min}$ at $40 \mathrm{~W}$ and 4 min at $80 \mathrm{~W}$ ) the workload was increased every minute with $20 \mathrm{~W}$ until exhaustion. The $\mathrm{W}_{\max }$ was calculated using the total time cycled at the exercise test. The highest workload completed for $1 \mathrm{~min}\left(\mathrm{~W}_{\text {completed }}\right)$ and the number of seconds $(X)$ that the final increase of $20 \mathrm{~W}$ was maintained were added according to the formula: $\mathrm{W}_{\max }=\mathrm{W}_{\text {completed }}+[(\mathrm{X} / 60) \times 20]$. Criteria for maximal performance were forced ventilation, leveling off of oxygen uptake, or a respiratory exchange ratio above 1.1. The oxygen uptake during the test was measured continuously using a computerized open system (Oxycon Beta, Mijnhardt, Bunnik, The Netherlands).

Data analysis. In the text, table and figure data are presented as means \pm SD. In the present study the effect of 12 mo of endurance training on leptin concentration in weightreduced males was examined. The data measured at 10 and 16 mo were therefore averaged, and the change in parameter $(\Delta)$ was compared with the change in parameter during the 4-mo treatment. Regain of the parameter during theintervention period (4-16 mo) is expressed as a percentage of the treatment period (0-4 mo). However, factors known to be related to leptin, such as insulin concentration and body fat percentage, could disturb the relationship between exercise and leptin. This relationship should therefore be studied by means of partial regression analysis, to correct for changes in insulin concentration and body fat percentage. The amount of variance explained by the factors leptin, insulin, and body fat percentage then can be evaluated with multiple regression analysis.

Statistical analysis. Differences between the group that trained continuously and the group that had stopped training after 4 mo were tested nonparametrically with the MannWhitney test. Partial correlation coefficients (pcc) were cal culated by use of residual sum of squares of multiple (RSS2) and simple regression analysis (RSS1), that is, $\sqrt{(\mathrm{RSS1}-\mathrm{RSS2}) / \mathrm{RSS1}}$. Multiple regression analysis was used to calculate the amount of explained variance of the variables. For all statistics performed statistical significance was set at $\mathrm{P}<0.05$

\section{RESULTS}

Physical characteristics of the 15 male participants are presented in Table 1. No significant differences were found in baseline characteristics between the trained and the control group. At 4 mo, physical characteristics appeared to be similar too (data partly shown in Table 2).

Training intervention. The effectiveness of the training intervention studied is examined by comparison of the training status of the two groups. In Table 3 the $\mathrm{VO}_{2 \text { max }}$ and $\mathrm{W}_{\text {max }}$ measured at the maximal performance test are presented for the two groups, expressed per kilogram body weight. 
Table 1. Physical characteristics of obese males beforestudy

\begin{tabular}{lcc}
\hline \hline & $\begin{array}{c}\text { Trained } \\
\mathrm{n}=7\end{array}$ & $\begin{array}{c}\text { Control } \\
\mathrm{n}=8\end{array}$ \\
\hline Age, $\mathrm{yr}$ & $38.0 \pm 3.9$ & $36.6 \pm 6.3$ \\
Body wt, $\mathrm{kg}$ & $93.1 \pm 14.5$ & $99.5 \pm 12.9$ \\
Height, $\mathrm{m}$ & $1.76 \pm 0.07$ & $1.77 \pm 0.13$ \\
$\mathrm{BMI}, \mathrm{kg} \cdot \mathrm{m}^{-2}$ & $29.8 \pm 3.0$ & $31.8 \pm 2.3$ \\
WHR & $0.95 \pm 0.04$ & $0.96 \pm 0.04$ \\
$\mathrm{D}_{\text {sag }} \mathrm{cm}$ & $22.7 \pm 2.2$ & $24.8 \pm 2.2$ \\
Body fat, \% & $28.0 \pm 3.4$ & $31.0 \pm 3.0$ \\
W $_{\max }, \mathrm{W} / \mathrm{kg}$ body wt & $2.7 \pm 0.3$ & $2.6 \pm 0.2$ \\
OO $_{2 \text { max }}, \mathrm{ml} \cdot$ min $^{-1} \cdot \mathrm{kg}$ body $\mathrm{wt}^{-1}$ & $32.8 \pm 3.2$ & $31.3 \pm 4.8$ \\
\hline
\end{tabular}

Values are means $\pm \mathrm{SD} ; \mathrm{n}=$ no. males. $\mathrm{BMI}$, body mass index WHR, waist/hip ratio; $D_{\text {sag }}$, sagittal distance between umbilicus and back; $\mathrm{W}_{\max }$, maximal power output; $\mathrm{V}_{2 \max }$, maximal oxygen uptake.

The training status parameters $\dot{\mathrm{V}}_{2 \max }$ and $\mathrm{W}_{\max }$ were equal at the beginning of the study and at 2 and 4 mo. The group that continued the training sessions showed significantly higher power output levels and $\mathrm{Vo}_{2 \max }$ at 10 and $16 \mathrm{mo}$. On the basis of these differences found in training status we can compare these groups and study the effect of differences in training status.

Anthropometry and blood parameters. In Table 2 the parameters body weight, BMI, body fat percentage, $W H R$, and $D_{\text {sag }}$ are shown for the entire period for the trained and control groups. Body fat percentage determined with the deuterium dilution technique was significantly lower for the trained compared with the control group at $16 \mathrm{mo}$ (at $10 \mathrm{mo}, \mathrm{P}=0.06$ ). Significant differences were also found between the groups with respect to WHR at 16 mo. The leptin concentration decreased for both groups during the VLED (0-2 mo) from $10.7 \pm 5.1$ to $3.1 \pm 1.3 \mathrm{ng} / \mathrm{ml}$ for all subjects (no differences between the two groups). During the intervention period, leptin concentration changed significantly and was different between the two groups at 10 and $16 \mathrm{mo}$. For the insulin concentrations no differences were found between the groups over the entire period.

Regain of waist, WHR, and $D_{\text {sag }}$ during the intervention period ( $\Delta 4-16 \mathrm{mo}$ ) was significantly less for the trained compared with the control group (Fig.1). Signifi- cantly less regain of waist, WHR, and $D_{\text {sag }}$ was found for the trained compared with the control group.

Relationship of insulin, body fat percentage, and exercise with leptin. The relationship between body fat percentage and leptin was studied by relating the change in body fat percentage during the 2-mo VLED with the change in leptin concentration over the same period. Partial regression analysis revealed that the change in body fat percentage was not correlated with the changes in leptin ( $\mathrm{pcc}=0.27$, not significant). However, the change in insulin was correlated with the changes in leptin concentration $(\mathrm{pcc}=0.79, \mathrm{P}<0.01$ ). The change in body fat percentage during the intervention period ( $\Delta 4-16 \mathrm{mo})$ was, however, significantly correlated with the change in leptin concentration during this same period $(r=0.68, P<0.05)$ (Fig.2).

With simple regression analysis a relationship was found between $\mathrm{V}_{\mathrm{O}_{2 \max }}(\mathrm{kg}$ body $\mathrm{wt}$ ) and leptin levels with training (on average over the four time points $r=-0.57 \pm 0.1, P<0.05)$. Before the training intervention no such relationship was found $(r=-0.08$, $P=0.79$ ). The effect of training on plasma leptin levels was further analyzed using partial regression analyses (Table 4).

Changes in insulin, body fat percentage, and number of training hours per week of all subjects were analyzed in relation to leptin levels measured, when corrected for possible interactions. As found for changes during the VLED, changes in leptin levels over the entire period were related to changes in insulin $(p c c=0.47$, $\mathrm{P}<0.05$ ). During this time period, a trend for changes in body fat percentage affecting leptin changes was al so found ( $p c c=0.42, P=0.07$ ). Analysis of the influence of training hours when the change in body fat percentage and the change in insulin were kept constant showed a pcc of $0.56(P<0.05)$, indicating that training was an independent factor correlated with changes in leptin levels. Multiple regression analysis of two variables ( $\Delta$ insulin and $\Delta$ body fat percentage) explained $44 \%$ of the variance of leptin. Inclusion of the amount of training hours resulted in a significant increase in explained variation to $61 \%$.

Table 2. Effect of exerciseintervention on physical parameters

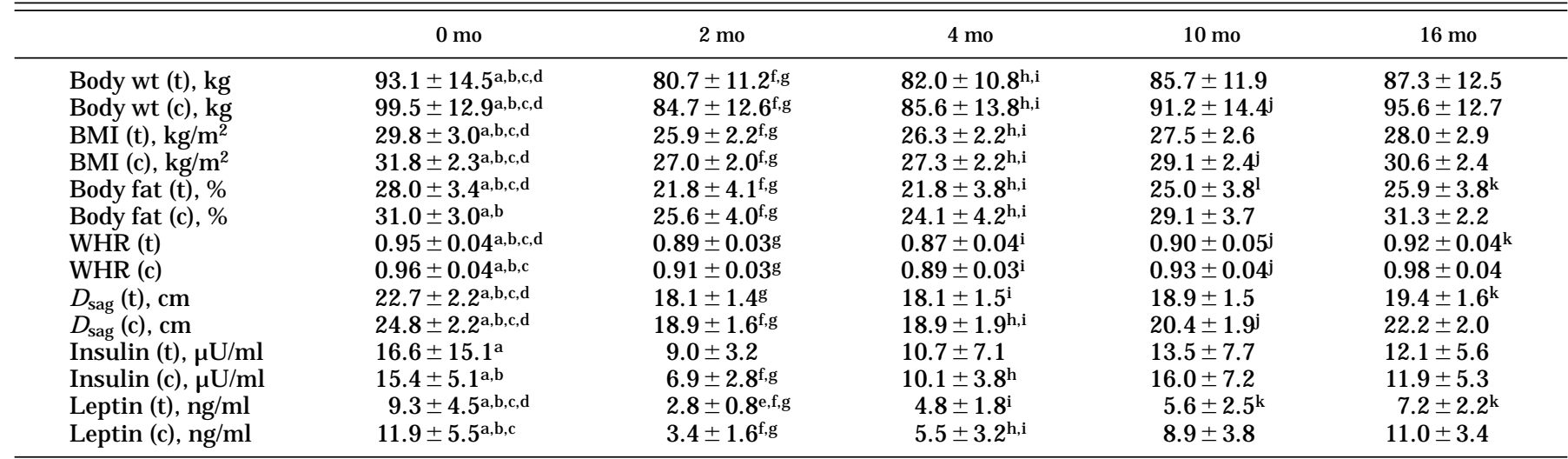

Values are means \pm SD for trained $(t ; n=7)$ control $(c ; n=8)$ groups. Significant differences $(P<0.05):{ }^{a}$ month 0 vs. $2,{ }^{b}$ month 0 vs. $4,{ }^{c}$ month 0 vs. $10,{ }^{d}$ month 0 vs. $16,{ }^{e}$ month 2 vs. $4,{ }^{f}$ month 2 vs. $10,{ }^{9}$ month 2 vs. $16,{ }^{h}$ month 4 vs. $10,{ }^{i}$ month 4 vs. $16,{ }^{j}$ month 10 vs. $16 .{ }^{k} P<0.05$ between groups. ${ }^{\prime} \mathrm{P}=0.06$ between groups. 
Table 3. Effect of exerciseintervention on training status

\begin{tabular}{|c|c|c|c|c|c|}
\hline & $0 \mathrm{mo}$ & $2 \mathrm{mo}$ & $4 \mathrm{mo}$ & $10 \mathrm{mo}$ & $16 \mathrm{mo}$ \\
\hline
\end{tabular}

Values are means $\pm S D ; n=7$ trained and 8 controls. $W_{\max }$, maximal power output at bicycle ergometer test $(\mathrm{W} / \mathrm{kg}$ body $\mathrm{wt}) ; \dot{V}_{\mathrm{O}_{2} \text { max }}$ maximal oxygen consumption $\left(\mathrm{ml} \cdot \mathrm{kg}\right.$ body $\left.\mathrm{wt}^{-1} \cdot \mathrm{min}^{-1}\right)$. Maximal performance and maximal oxygen uptake at different time points. Significant differences ( $P<0.05)$ : ${ }^{a}$ month 0 vs. $2,{ }^{b}$ month 0 vs. $4,{ }^{c}$ month 0 vs. $10,{ }^{d}$ month 0 vs. $16,{ }^{e}$ month 2 vs. $4,{ }^{f}$ month 2 vs. $10,{ }^{9}$ month 2 vs. $16,{ }^{\mathrm{h}}$ month 4 vs. $10,{ }^{i}$ month 4 vs. $16 .{ }^{\mathrm{j}} \mathrm{P}<0.05$ between groups. ${ }^{\mathrm{k}} \mathrm{P}=0.09$ between groups.

\section{DISCUSSION}

Exercise. The main result of this study is the independent effect of training on leptin concentration. So far no studies are known in humans in which an effect of exercise training on leptin concentration is reported independent of body fat and insulin levels. Because the trained group had significantly lowered leptin levels after $1 \mathrm{yr}$ of exercise training, we analyzed the independent effect of training on leptin levels when corrected for the changes in insulin and body fat percentage during the long-term exercise intervention. The number of training hours a week correlated significantly with the changes found in leptin levels. Recently it was found that sex steroid hormones too were independent of body fat related to leptin levels (9).

Because it is known that some obese subjects overestimate their physical activity (16), the training sessions were continuously visited by the investigator (W. J . Pasman) and training diaries were frequently examined to be certain that reliable training data were obtained. The relationship found between training hours and leptin may suggest that exercise effectively resulted in reduced leptin secretion or an elevated elimination of leptin. This effect was not found at $10 \mathrm{mo}$ of the study, indicating that the duration of training and the difference in training status between the two

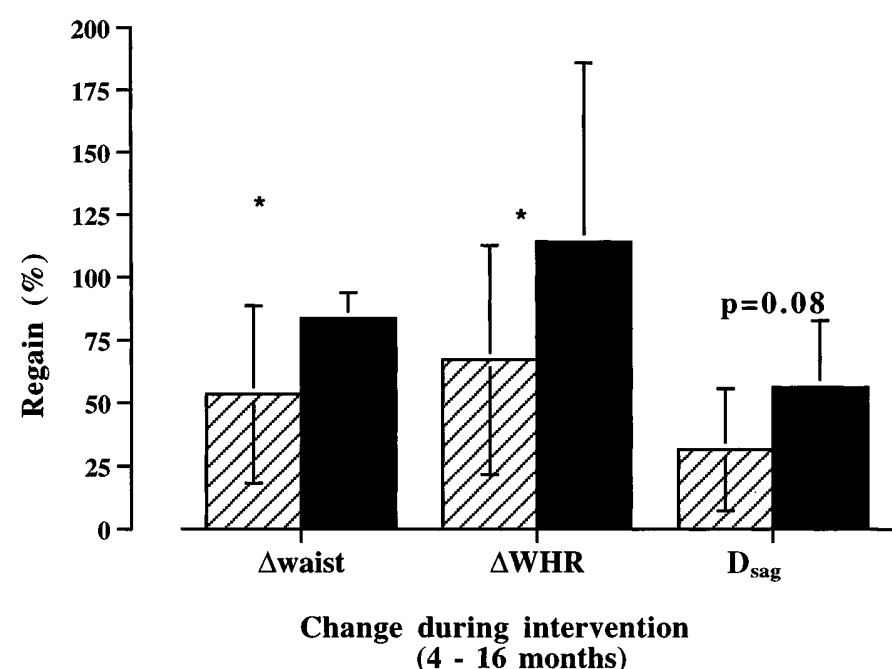

Fig. 1. Regain of anthropometric parameters at 16 mo (increase is expressed as percentage of amount lost during 4 mo of treatment). Increase in waist ( $\Delta$ waist), waist-to-hip ratio $(\Delta \mathrm{WHR})$, and sagittal diameter $\left(\Delta D_{\text {sag }}\right)$ are presented for trained (hatched bars) and control groups (filled bars). * Statistical significance was set at $P<0.05$. groups might be important. Our findings could not be explained by the pulsatile leptin secretion recently reported by Licinio and co-workers (17), because we sampled blood at the same standardized moments of the day. Our findings are supported by the results of Hickey and co-workers (12), who reported that male trained distance runners al so had reduced leptin levels. In another study Hickey et al. (13) found a reduction in serum leptin levels in female subjects after a 12-wk training intervention, which was not found in the participating males. This might indicate that the duration of the training intervention is important especially for males. The $17.5 \%$ reduction in serum leptin level found by Hickey et al. (13) was less than the reduction of $23 \%$ in our study. A study of Kohrt and colleagues (14) in el derly women (aged 60-72 yr) further indicates that women show lowered leptin levels in response to exercise. The $23 \%$ reduction in leptin levels found in that training group was similar to the level found in the male population in the present study. Low levels of leptin were also found in highly trained women vs. controls by Ryan and Elahi (28). All results support the suggestion that training lowers leptin levels. Hickey and co-workers (13) suggest that the gender-specific response to training is based on the difference in insulin-resistance between males and females; males being the most insulin-resistant might need more time and a greater stimulus to respond with lowered leptin levels. According to Kohrt et al. the reduction in leptin concentration is an indirect consequence of exercise; the reduction in fat mass, caused by training, seemed to be the main factor related to leptin (14). This is in contrast to the findings in the present study. After correction of the relationship of leptin with body fat percentage and insulin, we found a clear relationship in regard to the amount of training performed a week. Perhaps the clear difference in exercise protocol in the studies (intensity and duration per training session in the present study were higher and longer) and the participating subjects (male, middle-aged subjects vs. el derly females in the study by Kohrt et al.) can explain the differences found in relation to training and leptin. The recently published results of Pérusse and coworkers (25) and Ostlund and co-workers (23) also stress the relationship between leptin and exercise via the changes in body fat. The much longer training period in the present study (16 vs. 4-5 mo) might explain the independent effect of training found in the present study, whereas Pérusse and co-workers 


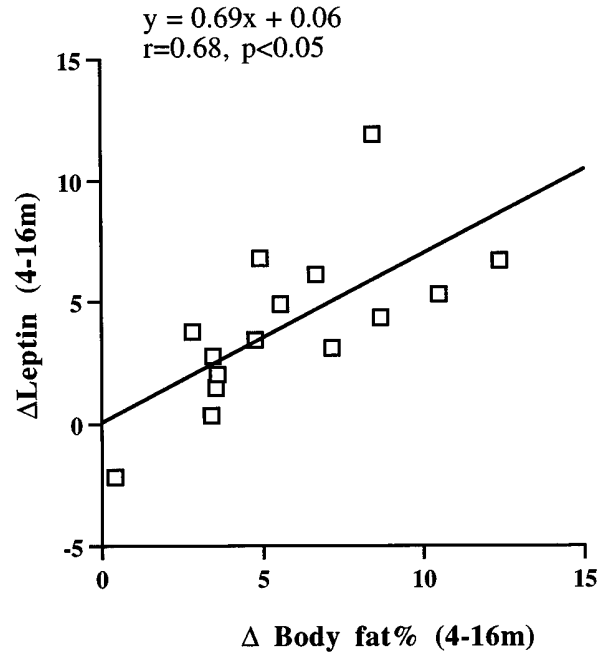

Fig. 2. Relationship between change in body fat percentage during intervention (4-16 mo) and change in leptin concentration (open squares). Regression line and correlation are presented.

found that after correction for fat mass no effect of exercise was seen. As mentioned previously at $10 \mathrm{mo}$, no independent effect of training was found and therefore duration might be an important factor. The difference in BMI of the male subjects at the start of the study $\left(25.5 \pm 5.0 \mathrm{~kg} / \mathrm{m}^{2}\right)$ in comparison with the subjects participating in the present study $(29.8 \pm 3.0$ $\mathrm{kg} / \mathrm{m}^{2}$ ) (25) might further stress that exercise in obese subjects normalizes leptin levels, resulting in more pronounced effects in obese subjects. In the study by Ostlund et al., 106 subjects between 60 and $70 \mathrm{yr}$ old were included and thus only a low range of the $\mathrm{VO}_{2 \max }$ was examined.

Data for trained rats showed that endurancetraining significantly decreased the ob gene expression $(10,36)$. Insulin sensitivity and fat cell size were postulated to be important regulators of ob protein mRNA expression (36). The regulation is complex because exercise training not only influences obesity but also insulin resistance as well as body composition $(2,6)$. These three parameters are mutually related. All findings together suggest that exercise and leptin levels are causally related, although a spurious relationship or confounding factors such as a negative energy balance that could disturb the relationship cannot be ruled out. Our data support the existing relationship but do not inform us about cause and effect.

There may be another possibility that could explain the differences in leptin found in the trained and

Table 4. Partial correlation coefficients

\begin{tabular}{llcr}
\hline \hline $\begin{array}{c}\text { Partial } \\
\text { Correlation }\end{array}$ & \multicolumn{1}{c}{ Corrected For } & $r$ & \multicolumn{1}{c}{$\mathrm{P}$} \\
\hline$\Delta$ Insulin & $\Delta$ Body fat \% & 0.47 & $<0.05$ \\
$\Delta$ Body fat \% & $\Delta$ Insulin & 0.42 & 0.07 \\
Hours exercise & $\Delta$ Body fat \% and $\Delta$ insulin & 0.56 & $<0.05$ \\
\hline
\end{tabular}

Partial regression analysis of effect of changes in insulin ( $\Delta$ insulin) $\%$ changes in body fat ( $\Delta$ body fat $\%$ ), and hours of exercise training at changes in leptin levels during study intervention are presented. control group after 16 mo of exercise training. It has already been found that leptin is bound by plasma proteins (31). A change in ratio of leptin free or bound at plasma proteins might result in more or less active leptin action. The total amount of leptin could be stable but the ratio of bound and free leptin, and thereby the activity of leptin, might be changed by exercise training. Differences in the ratio of free and bound free fatty acids for example have al ready been found for trained vs. untrained subjects by Turcotte and co-workers (34).

Insulin and body fat percentage during VLED and long-term intervention. In the present study we found that 2 mo of energy restriction resulted in significantly lowered leptin levels in both groups as was found by others $(7,19)$. Partial regression analysis showed that changes in insulin levels during the energy-restricted period were significantly correlated with changes in leptin levels and that changes in body fat percentage were not related to changes in leptin levels. Also, a simple regression analysis between body fat percentage and leptin (directly after VLED at month 2) showed that these parameters were not related, which could be explained by the negative energy balance (extreme negative energy balance because of the VLED). This dissociation of serum leptin concentration and body fat content was recently also shown by Scholz and coworkers (30). They concluded that long-term hypocaIoric diet uncouples the relationship of leptin and changes in body fat (30). The low levels of leptin as we found after the diet intervention and still at 4 mo may precede weight gain, as was recently suggested by Ravussin and co-workers (26). A lower production of leptin by the adipose tissue may play a role in the pathophysiology of obesity but could also indicate that the sensitivity of the tissue to leptin has increased and that leptin concentration has ther efore been adapted. Further studies are needed to find out whether lowered leptin levels in blood are useful markers for the devel opment of obesity.

In the present study at 4 mo the subjects were weight stable, and no negative energy balance seemed to be present. Therefore, the differentiation between the groups from that time point on could be related only to exercise level and not to energy restriction. Partial regression analysis revealed that $\Delta$ insulin affected $\Delta$ leptin during VLED, indicating that insulin and leptin are related also when corrected for body fat percentage. The change in insulin significantly affected leptin levels, but in thelong term the changein body fat percentage influenced leptin levels. The change in body fat percentage over $1 \mathrm{yr}$ of training and the change in leptin during the intervention period were related (Fig.2). Together with the lowered leptin levels for the trained group, it is concluded that the regulation of insulin and leptin are interrelated, although the mechanism and direction behind this remain to be elucidated. Recently it was hypothesized that insulin would act as an up- and downregulator of leptin in lean rats, whereas in obese rats only upregulation works (8). Zheng and co-workers (38) reported that ob mRNA is upregulated by insulin infusion in abdominal adipose 
tissue of a fasted rat. I nsulin would be directly involved with the expression of ob mRNA at a transcriptional level as was found in cultured mature fat cells (15). Our data support the hypothesis that insulin might have a regulatory role in obese males, because, after correction of body fat percentage, clear relationships of insulin still exist with leptin. However, the direction of regulation, insulin-regulating leptin or leptin-regulating insulin, is still unclear, although Cohen and co-workers (5) and Taylor et al. (33) recently suggested that in vitro insulin is modulated by leptin. This interaction of insulin and leptin warrants further study.

Body fat percentage or body fat distribution? In the present study a relationship between body fat percentage and body fat mass with leptin was found (on average $r=0.76, \mathrm{P}<0.05$ for body fat percentage at all time points measured; with fat mass on average $r=$ $0.83, \mathrm{P}<0.05$; data not shown). This strong relationship has already been found by others $(7,18)$. The difference in body fat percentage between the trained and control group at 16 mo might be a consequence of the training sessions performed as has been shown before (35). The body composition differences are important because no significant differences in body weight and BMI were found at $16 \mathrm{mo}$. Therefore, the differences in body composition between the two groups could be important with respect to differences in leptin levels found.

However, fat distribution measured by WHR or $D_{\text {sag }}$ differed significantly between the two groups at the end of the study. In the present study we found significant differences during the intervention period in waist circumferences, $D_{\text {sag, }}$ and WHR between the two groups. The increased values for the control group might indicate that the extra regain of fat mass in the control group is probably located in the waist region. Simple regression analysis also revealed significant correlations between the change in waist, $\Delta \mathrm{WHR}$, and $\Delta \mathrm{D}_{\text {sag }}$ with the change in leptin during the exercise intervention period $(r=0.58, P<0.05 ; r=0.69, P<0.05 ; r=$ $0.59, \mathrm{P}<0.05$, respectively). These results are in accordance with the findings of Buemann and Tremblay (2), who reported that exercise training is negatively correlated with WHR. Mauriège and colleagues (21) also supported the hypothesis that the abdominal fat depot is decreased by training. Buemann and Tremblay further reported that upper body obese patients responded to exercise with increased insulin sensitivity. Exercise can thus increase insulin sensitivity by lowering percentage of body fat and fat accumulation in the waist region and result in decreased leptin levels perhaps via a regulation with insulin, which would be in favor of a role of the fat distribution. Regional differences in catecholamine-induced lipolysis (1) and site-specific differences in ob gene expression reported in rats (38), support the hypothesis that leptin production might be site specific. This is further supported by the results of Ryan and Elahi (28), who found that WHR but not other measures for abdominal obesity (trunk fat by dual X-ray absorption, abdominal subcutaneous fat, and $D_{\text {sag }}$ ) were as in the present study sig- nificantly related to leptin. However, Ostlund and co-workers (23) recently showed that there was no independent effect of fat distribution at leptin levels measured. Correction for body fat percentage resulted in a disappearance of the negative correlation found between WHR and leptin (23). In that study the majority of subjects were females (120 females vs. 84 males), which is in contrast to the homogeneous group of male subjects in the present study. The abdominal fat distribution found in males might be less obvious in a mixed population in contrast to our group of subjects. Furthermore, the differences in age range (in the present study 28-46 yr vs. 18-80 yr in the study of Ostlund et al.) might explain the differences found with fat distribution and leptin.

On the basis of the findings in the literature and our own data we conclude that the localization of the main fat depot might have consequences for the regulation of leptin metabolism. It is concluded that exercise training decreased plasma leptin levels independently of changes in plasma insulin levels and body fat percentage. In addition to training, the changes in body fat percentage and moreover changes in insulin seem to be affecting the regulation of leptin levels.

The authors thank Dr. A. Kester for statistical advice.

Address for reprint requests: W. J. Pasman, Maastricht Univ., Dept. of Human Biology, P. O. Box 616, 6200 MD Maastricht, The Netherlands.

Received 18 March 1997; accepted in final form 9 October 1997.

\section{REFERENCES}

1. Arner, P., L. Hellström, H. Wahrenberg, and M. Brönnegård. Beta-adrenoceptor expression in human fat cells from different regions. J . Clin. Invest. 86: 1595-1600, 1990.

2. Buemann, B., and A. Tremblay. Effects of exercise training on abdominal obesity and related metabolic complications. Sports Med. 21: 191-212, 1996.

3. Campfield, L., F. J . Smith, Y. Guisez, R. Devos, and P. Burn. Recombinant mouse ob protein: evidence for a peripheral signal linking adiposity and central neural networks. Science 269: 546-549, 1995

4. Clausen, J . O., K. Borch-J ohnsen, H. I bsen, R. N. Bergman, P. Hougaard, K. Winther, and O. Pedersen. Insulin sensitivity index, acute insulin response, and glucose effectiveness in a population-based sample of 380 young healthy caucasians. Analysis of the impact of the gender, body fat, physical fitness, and life-style factors. J. Clin. Invest. 98: 1195-1209, 1996.

5. Cohen, B., D. Novick, and M. Rubinstein. Modulation of insulin activities by leptin. Science274: 1185- 1188, 1996.

6. Colman, E., L. I. Katzel, E. Rogus, P. Coon, D. Muller, and A. P. Goldberg. Weight loss reduces abdominal fat and improves insulin action in middle-aged and older men with impaired glucose tolerance. Metabolism 44: 1502-1508, 1995.

7. Considine, R. V., M. K. Sinha, M. L. Heiman, A. Kriauciunas, T. W. Stephens, M. L. Nyce, J . P. Ohannesian, C. C. Marco, L. J . Mckee, T. L. Bauer, and J . F. Caro. Serum immunoreactive-leptin concentrations in normal weight and obese humans. N. Engl. J . Med. 334: 292-295, 1996.

8. Cusin, I., A. Sainsbury, P. Doyle, F. Rohner-J eanrenaud, and B. J eanrenaud. The ob gene and insulin. A relationship leading to clues to the understanding of obesity. Diabetes 44 1467-1470, 1995.

9. Elbers, J . M. H., H. Asscherman, J . C. Seidell, M. Frölich, A. E. Meinders, and L. J . G. Gooren. The effect of cross-sex hormonal treatment on serum leptin levels in transsexuals. Int. J . Obes. 21, Suppl. 2: S14, 1997.

10. Friedman, J . E., K. S. Aulak, C. M. Ferrara, S. A. McCune, S. Park, and W. M. Sherman. Exercise training decreases expres- 
sion of obesity gene (ob) in adipose tissue of obese SHHF/M cc-fa rats (Abstract). FASEB J . 10: A186, 1996.

11. Halaas, J . L., K. S. Gajiwala, M. Maffei, S. L. Cohen, B. T. Chait, D. Rabinowitz, R. L. Lallone, S. K. Burley, and J . M. Friedman. Weight-reducing effects of the plasma protein encoded by the obese gene. Science 269: 543-546, 1995.

12. Hickey, M. S., R. V. Considine, R. G. Israel, T. L. Mahar, M. R. McCammon, G. L. Tyndall, J . A. Houmard, and J . F. Caro. Leptin is related to body fat content in male distance runners. Am. J. Physiol. 271 (Endocrinol. Metab. 34): E938E940, 1996.

13. Hickey, M. S., J . A. Houmard, R. V. Considine, G. L. Tyndall, J . B. Midgette, K. E. Gavigan, M. L. Weidner, M. R. McCammon, R. G. I srael, and J . F. Caro. Gender-dependent effects of exercise training on serum leptin levels in humans. Am. J. Physiol. 272 (Endocrinol. Metab. 35): E562-E566, 1997.

14. Kohrt, W. M., M. Landt, and S. J . Birge. Serum leptin levels are reduced in response to exercise training, but not hormone replacement therapy, in ol der women. J . Clin. Endocrinol. Metab. 81: 3980-3985, 1996.

15. Leroy, P., S. Dessolin, P. Villageois, B. C. Moon, J . M. Friedman, G. Ailhaud, and C. Dani. Expression of ob gene in adipose cells. Regulation by insulin. J . Biol. Chem. 271: 23652368, 1996.

16. Lichtman, S. W., K. Pisarska, E. R. Berman, M. Pestone, H. Dowling, E. Offenbacher, H. Weisel, S. Heshka, D. E. Matthews, and S. B. Heymsfield. Discrepancy between selfreported and actual cal oric intake and exercise in obese subjects. N. Engl. J . Med. 327: 1893-1898, 1992.

17. Licinio, J ., C. Mantzoros, A. B. Negrao, G. Cizza, M.-L. Wong, P. B. Bongiorno, G. P. Chrousos, B. Karp, C. Allen, J . S. Flier, and P. W. Gold. Human leptin levels are pulsatile and inversely related to pituitary-adrenal function. Nat. Med. 3: 575-579, 1997.

18. Lönnqvist, F., P. Arner, L. Nordfors, and M. Schalling. Overexpression of the obese (ob) gene in adipose tissue of human obese subjects. Nat. Med. 1: 950-953, 1995.

19. Maffei, M., J . Halaas, E. Ravussin, R. E. Pratley, G. H. Lee, Y. Zhang, H. Fei, S. Kim, R. Lallone, S. Ranganathan, P. A. Kern, and J . M. F riedman. Leptin levels in human and rodent: measurement of plasma leptin and ob RNA in obese and weightreduced subjects. Nat. Med. 1: 1155-1161, 1995.

20. Marken Lichtenbelt, W. D. V., K. R. Westerterp, and L. Wouters. Deuterium dilution as a method for determining total body water: effect of test protocol and sampling time. Br.J . Nutr. 72: 491-497, 1994

21. Mauriège, P., D. Prud'homme, M. Marcotte, M. Yoshioka, A. Tremblay, and J .-P. Deprés. Chronic adaptation of adipose tissue metabolism to endurance training: existence of regional differences. Int. J . Obes. 20, Suppl. 4: 66, 1996.

22. McGarry, J . D. Does leptin lighten the problem of obesity? Curr. Biol. 5: 1342-1344, 1995.

23. Ostlund, R. E., J. W. Yang, S. Klein, and R. Gingerich. Relation between plasma leptin concentration and body fat, gender, diet, age, and metabolic covariates. J . Clin. Endocrinol. Metab. 81: 3909-3913, 1996.

24. Pelleymounter, M. A., M. J . Cullen, M. B. Baker, R. Hecht, D. Winters, T. Boone, and F. Collins. Effects of the obese gene product on body weight regulation in ob/ ob mice. Science 269: 540-543, 1995
25. Pérusse, L., G. Collier, J . Gagnon, A. S. Leon, D. C. Rao, J . S. Skinner, J . H. Wilmore, A. Nadeau, P. Zimmel, and C. Bouchard. Acute and chronic effects of exercise on leptin levels in humans. J . Appl. Physiol. 83: 5- 10, 1997.

26. Ravussin, E., R. E. Pratley, M. Maffei, H. Wang, J . M. Friedman, P. H. Bennet, and C. Bogardus. Relatively low plasma leptin concentrations precede weight gain in Pima Indians. Nat. Med. 3: 238-240, 1997.

27. Rohner-J eanrenaud, F., and B. J eanrenaud. Obesity, leptin and the brain. N. Engl. J . Med. 334: 324- 325, 1996.

28. Ryan, A. S., and D. Elahi. The effects of acute hyperglycemia and hyperinsulinemia on plasma leptin levels: its relationships with body fat, visceral adiposity, and age in women. J. Clin. Endocrinol. Metab. 81: 4433-4438, 1996.

29. Schoeller, D.A., and P.J . H.J ones. Measurement of total body water by isotopic dilution: a unified approach to calibrations. In In Vivo Body Composition Studies, edited by K. J. Ellis, S. Yasumura, and W. D. Morgan. London: Inst. of Phys. Sci. in Med. 1987, p. 131-136.

30. Scholz, G. H., P. Englaro, I. Thiele, M. Scholz, T. Klusmann, K. Kellner, W. Rascher, and W. F. Blum. Dissociation of serum leptin concentration and body fat content during long term dietary intervention in obese individuals. Horm. Metab. Res. 28: 718-723, 1996

31. Sinha, M. K., I. Opentanova, J. P. Ohannesian, J. W. Kolaczynski, M. L. Heiman, J . Hale, G. W. Becker, R. R. Bowsher, T. W. Stephens, and J . F. Caro. Evidence of free and bound leptin in human circulation. Studies in lean and obese subjects and during short-term fasting. J . Clin. Invest. 98: 1277-1282, 1996

32. Stephens, T. W., M. Basinski, P. K. Bristow, J. M. BueValleskey, S. G. Burgett, L. Craft, J . Hale, J . Hoffmann, H. M. Hsiung, A. Kriauciunas, W. MacKellar, P. R. Rosteck, J r., B. Schoner, D. Smith, F. C. Tinsley, X.-Y. Zhang, and M. Heiman. The role of neuropeptide $Y$ in the antiobesity action of the obese gene product. Nature 377: 530-532, 1995.

33. Taylor, S. I., V. Barr, and M. Reitman. Does leptin contribute to diabetes caused by obesity? Science274: 1151-1152, 1996.

34. Turcotte, L. P., E. A. Richter and B. Kiens. I ncreased plasma FFA uptake and oxidation during prolonged exercise in trained vs. untrained humans. Am. J . Physiol. 262 (Endocrinol. Metab. 25): E 791-E 799, 1992.

35. Westerterp, K. R., G. A. L. Meijer, E. M. E.J anssen, W. H. M. Saris, and F. ten Hoor. Long-term effect of physical activity on energy balance and body composition. Br. J . Nutr. 68: 21-30, 1992.

36. Zachwieja, J . J ., R. B. S. Harris, and S. R. Smith. Voluntary wheel running normalizes insulin resistance and reduces ob mRNA expression in adipose tissue of Osborne-Mendel rats (Abstract). FASEB J . 10: A218, 1996.

37. Zhang, Y., R. Proenca, M. Maffei, M. Barone, L. Leopold and J . M. Friedman. Positional cloning of the mouse obese gene and its human homologue. Nature 372: 425-432, 1994.

38. Zheng, D., J. P. J ones, S. J. Usala, and G. L. Dohm Differential expression of ob mRNA in rat adipose tissue in response to insulin. Biochem. Biophys. Res. Commun. 218: 434-437, 1996. 